\title{
EFFECTS OF DIFFERENT NEUROMUSCULAR TRAINING PROTOCOLS ON THE FUNCTIONAL CAPACITY OF ELDERLY WOMEN
}

\author{
EFEITOS DE DIFERENTES PROTOCOLOS DE TREINAMENTO NEUROMUSCULAR SOBREA CAPACIDADE \\ FUNCIONAL DEIDOSAS \\ EFECTOS DE DIFERENTES PROTOCOLOS DE ENTRENAMIENTO NEUROMUSCULAREN LA CAPACIDAD \\ FUNCIONALDEANCIANAS
}

\begin{abstract}
Antônio Gomes de Resende Neto (Physical Education Professional)

Marta Silva Santos'

(Physical Education Professional)

Roberto Jerônimo Santos Silva'

(Physical Education Professional)

Josimari Melo de Santana²

(Physiotherapist)

Marzo Edir Da Silva-Grigoletto'

(Physical Education Professional)

1. Universidade Federal de Sergipe, Centro de Ciências Biológicas e da Saúde, Programa de Pós-Graduação em Educação Física, Department of Physical Education, São Cristóvão,

Sergipe, Brazil.

2. Universidade Federal de Sergipe, Centro de Ciências Biológicas e da

Saúde, Programa de Pós-Graduação em Ciências da Saúde, Department of Physiotherapy, São Cristóvão, Sergipe, Brazil.
\end{abstract}

\section{Correspondence:}

Rua Napoleão Dórea, 165, Apto. 03, Residencial Ana Carolina, Bairro Atalaia, Aracaju, SE, Brazil. 49037-460.

pit_researcher@yahoo.es

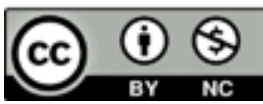

\begin{abstract}
Introduction: Several strength training protocols have been tested in the search for systemic adaptations to improve functionality in the elderly. For this purpose, integrated exercises aimed at improving essential movements can be an interesting strategy to improve the performance of activities of the daily living. Objective: To compare the effects of eight weeks of functional training with traditional strength training on the physical fitness of sedentary elderly women. Methods: Thirty-two elderly women were divided into functional training group ( $F T, n=16)$ and traditional training group $(T T, n=16)$. For the verification of functional responses, the Senior Fitness Test battery was used, as well as complementary tests of strength and muscular power. The data were analyzed using a 2×2 ANOVA with post hoc Sidak test to verify the differences between the groups. Results: At the end of eight weeks, when compared to TT group, the FT group showed significant increases in balance/ agility variables $(p=0.01 ;+7.6 \%)$, lower limbs strength $(p=0.04 ;+15.3 \%)$, upper limbs strength $(p=0.05 ;+11.7 \%)$, and cardiorespiratory power $(\mathrm{p}=0.05 ;+10.7 \%)$. However, in relation to flexibility tests and conventional tests of maximum dynamic force and muscular strength, there were no statistically significant differences between the groups. Conclusions: Both interventions are efficient to improve physical fitness of sedentary elderly women; however, functional training induces better adaptive responses to functionality when compared with traditional training. Level of Evidence l; Randomized clinical trial.
\end{abstract}

Keywords: Aging; Activities of daily living; Exercise.

\section{RESUMO}

Introdução: Atualmente diversos protocolos de treinamento de força vêm sendo testados na busca de adaptações sistêmicas para melhorar a funcionalidade em idosos. Com esse propósito, exercícios integrados e direcionados para o aprimoramento de movimentos essenciais podem ser uma estratégia interessante para melhorar o desempenho das atividades da vida diária. Objetivo: Comparar os efeitos de oito semanas de treinamento funcional com exercícios de força tradicionais sobre a aptidão física de idosas sedentárias. Métodos: Trinta e duas idosas foram divididas nos grupos treinamento funcional (TF, $n=16$ ) e treinamento tradicional (TT, $n=16$ ). Para a verificação das respostas funcionais foi utilizada a bateria Senior Fitness Test, além de testes complementares de força e de potência muscular. Os dados foram analisados a partir de uma ANOVA $2 \times 2$ com teste post hoc de Sidak para verificar as diferenças entre os grupos. Resultados: Ao final das oito semanas, quando comparado com o grupo TT, o grupo TF apresentou aumentos significativos nas variáveis equilíbrio/agilidade $(p=0,01 ;+7,6 \%)$, força de membros inferiores $(p=0,04$; $+15,3 \%)$, força de membros superiores $(p=0,05 ;+11 \%)$ e capacidade cardiorrespiratória $(p=0,05 ;+10,7 \%)$. Entretanto, com relação aos testes de flexibilidade e testes convencionais de força dinâmica máxima e potência muscular não se verificaram diferenças estatisticamente significativas entre os grupos. Conclusões: Ambas as intervenções são eficientes para melhorar a aptidão física de idosas sedentárias; entretanto, o treinamento funcional induz melhores respostas adaptativas à funcionalidade quando comparado com o treinamento tradicional. Nível de Evidência l; Ensaio clínico randomizado.

Descritores: Envelhecimento; Atividades diárias; Exercício.

\section{RESUMEN}

Introducción: Actualmente varios protocolos de entrenamiento de fuerza vienen siendo probados en la búsqueda de adaptaciones sistémicas para mejorar la funcionalidad en adultos mayores. Con este propósito, ejercicios integrados y dirigidos hacia el perfeccionamiento de movimientos esenciales pueden ser una estrategia interesante para mejorar el rendimiento en las actividades diarias. Objetivo: Comparar los efectos de ocho semanas de entrenamiento funcional con ejercicios de fuerza tradicional sobre la aptitud física de ancianas. Métodos: Treinta y dos ancianas fueron divididas en los grupo entrenamiento funcional $(E F, n=16)$ y entrenamiento tradicional $(E T n=16)$. Para la 
verificación de las respuestas funcionales se utilizó la batería Senior Fitness Test, además de pruebas complementarias de fuerza y de potencia muscular. Los datos fueron analizados a partir de una ANOVA $2 \times 2$ con prueba post hoc de Sidak para verificar las diferencias entre los grupos. Resultados: Al final de las ocho semanas, cuando se comparó con el grupo ET, el grupo EF mostró aumentos significativos en las variables equilibrio/agilidad ( $p=0,01 ;+7,6 \%)$, fuerza de las extremidades inferiores $(p=0,04 ;+15,3 \%)$, la fuerza de las extremidades superiores $(p=0,05 ;+11 \%)$ y la capacidad cardiorrespiratoria ( $p=0,05 ;+10,7 \%)$. No obstante, con respecto a las pruebas de flexibilidad, pruebas convencionales de fuerza dinámica máxima y potencia muscular no fueran verificadas diferencias estadísticamente significativas entre los grupos. Conclusiones: Ambas intervenciones son eficientes para mejora de la aptitud física de las personas mayores sedentarias; sin embargo, el entrenamiento funcional induce mejores respuestas adaptativas a la funcionalidad en comparación con el entrenamiento tradicional. Nivel de Evidencia l; Ensayo clínico Aleatorizado.

Descriptores: Envejecimiento; Actividades cotidianas; Ejercicio.

\section{INTRODUCTION}

Regular practice of strength training is capable of promoting numerous adaptations favorable to the health and quality of life of the elderly, particularly in the improvement of physical capacities related to functionality and structural alterations such as increased muscle mass and bone mineral density, reduced adipose tissue and resistance of connective tissue. ${ }^{1-3}$ Nowadays, several strength training protocols have been tested in the search for systemic adaptations to more effectively reduce the negative changes that result from the human aging process.

Traditional protocols applied with machines predominantly use analytical exercises with isolated neuromuscular work. Despite their proven efficiency ${ }^{3}$, their ability to translate into activities of daily living has been questioned ${ }^{4}$. Studies comparing different neuromuscular training protocols have shown that the benefits of exercises depend on tasks performed during training, and greater gains in functional capacity require specific movements for daily tasks, so as to prevent the onset of physical disabilities. . $^{5-7}$

In this context, functional training (FT) arises with the basic premise of training the psychobiological system in an integral way. This new method is based on the application of a systematized program of integrated, multi-articular and multi-planar exercises aimed at improving movement ability, the strength of the CORE region, and neuromuscular efficiency for the specific needs of each individual., 8

With the application of a 12-weeks functional exercise circuit, Whitehurst et al. ${ }^{10}$ reported an improvement of 14\% in flexibility, $8.4 \%$ in agility, $12.9 \%$ in balance, $7.4 \%$ in cardiorespiratory capacity, and $8.5 \%$ in physical function of the elderly. Milton et al. ${ }^{11}$ applied a 12- week functional exercise intervention and showed an improvement of 43\% in shoulder flexibility, 13\% in agility/dynamic balance, 14\% in upper body strength, 13\% in lower body strength, and $7 \%$ in cardiorespiratory fitness, when compared to the control group.

Thus, FT can be an important training method for improvement of innumerable factors resulting from advancing age. However, because the literature is still inconclusive and has many biases in the application of FT, the aim of the present investigation was to compare the effects of eight weeks of FT with a traditional strength training program in the physical fitness of sedentary older women. The hypothesis was that exercises based on daily activities are more effective in promoting significant increases in functional fitness of these individuals.

\section{MATERIALS AND METHODS}

A randomized clinical trial was conducted aiming at the analysis of two different types of physical training, controlling the action of intervening factors and describing the behavior of the variables observed in the intervention. ${ }^{12}$ The experimental design of the study is presented in Figure 1.
Thirty-two sedentary older women (65.6 \pm 4.6 years) were recruited through distribution of leaflets and then distributed through block randomization into two distinct groups: Functional Training ( $F T, n=16)$ and Traditional Training (TT, $n=16)$. The inclusion criterion was the absence of history of cardiovascular, neuromuscular and metabolic diseases; the observation of this criterion conducted a medical professional. After the training period, participants with an attendance of less than $75 \%$ or who had missed three consecutive training sessions were excluded from the analysis. The characteristics of the participants of the experimental groups are shown in Table 1.

The evaluation protocol consisted of an anamnesis with questions related to sociodemographic aspects, health characterization, type and quantity of medications used, presence of diseases and level of physical activity (report of activities of daily living and work). Finally, they were submitted to a nutritional assessment through a usual dietary recall, ${ }^{13}$ for control and normalization of diet during the training period.

Methodological procedures of the study were explained verbally and the elderly women agreed to voluntarily participate in the study, signing the informed consent form. The present study was approved by the Ethics Committee of the Federal University of Sergipe (no 1.021.732/ CAAE: 42022915.9.0000.5546).

The intervention lasted eight weeks, with a frequency of three weekly sessions of 60 minutes and a minimum recovery time of 48 hours between sessions. The OMNI-GSE ${ }^{14}$ scale was used to standardize and control the overall training intensity between the groups, where participants were instructed to indicate a single score that reflected their fatigue level during and after training, where "zero" represents none symptom and "ten" represents the maximum symptom of fatigue. During the whole session, it was moderate to intense levels of intensity were considered optimal (OMNI-GSE of 6-9).

The FT group of older women performed multifunctional, integrated and multi-articular exercises, specific to daily needs. Each session was divided into four blocks, as follows: $1^{\text {st }}-5$ minutes of joint mobility; $2^{\text {nd }}$ 15 minutes of intermittent activities organized in a circuit that required agility, coordination, velocity and muscle power of a set of complex motor systems; $3^{\text {rd }}$ - 25 minutes of multi-articular exercises for lower and upper limbs with intense activation of stabilizing muscles of the spine, organized in a circuit; and $4^{\text {th }}$ - 5 minutes of intermittent high-intensity activities.

TT subjects performed traditional exercises in machines, predominantly analytical exercises with isolated neuromuscular work. Each session was also divided into four blocks: $1^{\text {st }}-5$ minutes of joint mobility; $2^{\text {nd }}$ - 15 minutes of continuous aerobic rhythmic gymnastics requiring coordination, muscular and cardiorespiratory endurance; $3^{\text {rd }}-25$ minutes of analytical exercises for lower and upper limbs, organized in a circuit; and $4^{\text {th }}-5$ minutes of intermittent high-intensity activities. 


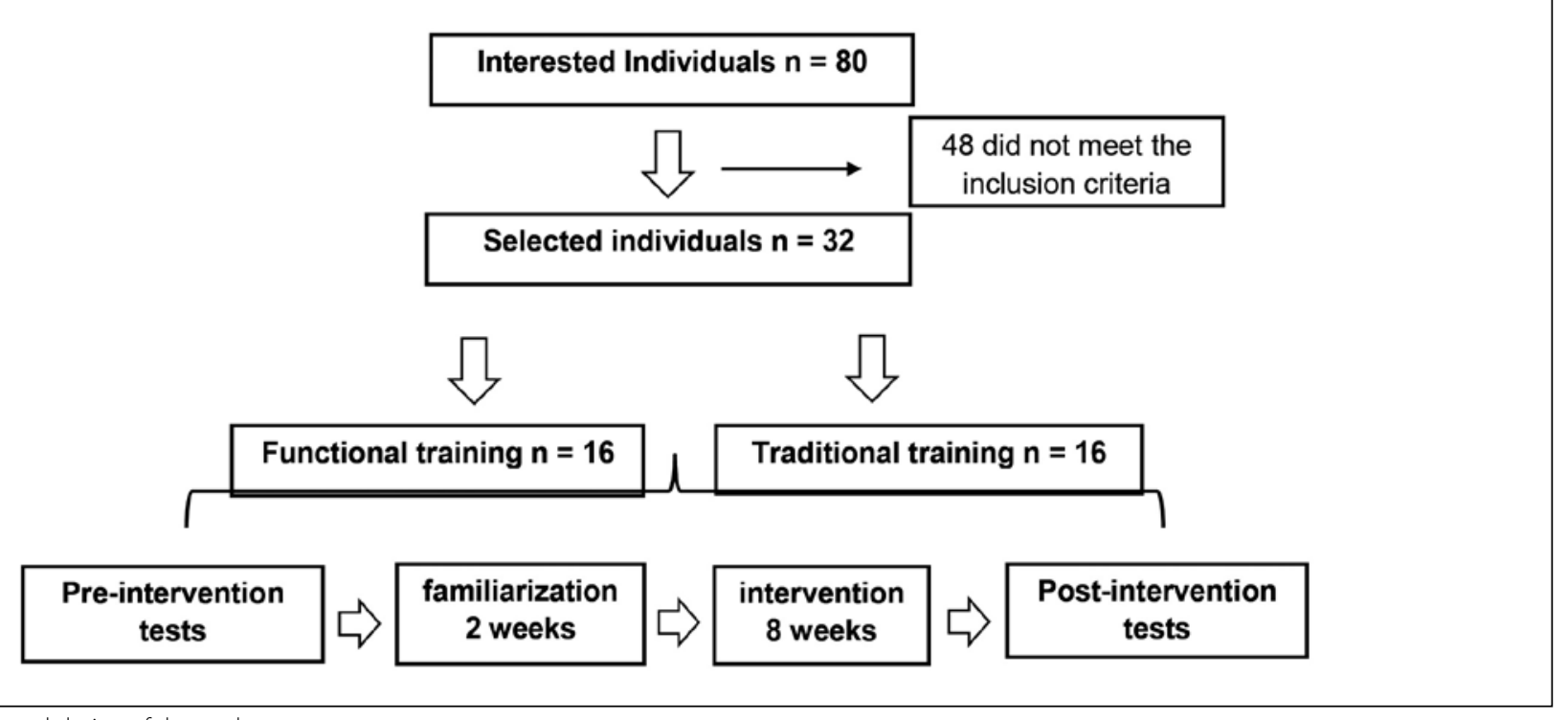

Figure 1. Experimental design of the study.

In the 3rd block, all participants trained in pairs and were supervised by experienced physical education professionals whose responsibility was to maintain the established protocols and ensure an optimal standard of safety and motivation. Seven experienced professionals per group were responsible for the same exercises in order to standardize the stimuli, during the intervention period.

In the case of the TT group, the addition of external load during the training period was based on a score 6 (easy) o15n the OMINI-GSE scale and with maintenance of 08 to 12 repetitions maximum. For the FT group, the same criterion for addition of external load in the possible exercises was followed; in the exercises performed with the own body mass, the criterion was modified according to the level of comfort and ability of the individual, in order to maintain 08 to 12 repetitions maximum. The training density was 1/1 (30 seconds of work and 30 seconds of active recovery to carry out the transition between stations). The general description of the 24 sessions of functional training and traditional strength training are described in Figure 2.

After the initial assessments, subjects in both groups went through two weeks of familiarization, where $50 \%$ of the planned intensity for the first session was applied, and then they completed the 24 training sessions.

Physical tests were performed in two days. On the first day, the Mini-Mental State Examination (MMSE), anthropometry test, maximum dynamic force test and the Senior Fitness Test battery were performed. On the second day, the power tests and the 6-minute walk test were performed.

The Mini-Mental State Examination (MMSE) ${ }^{15}$ is defined as a cognitive test consisting of a score that ranges from zero to 30 points that aims to provide data on various cognitive parameters of any geriatric population; the MMSE was used to better distribute the participants in the training programs.

The anthropometric evaluation included the body mass $(\mathrm{kg})$ which was measured through a scale (Lider ${ }^{\circledR}$, P150C, São Paulo, Brazil), with a maximum capacity of $150 \mathrm{~kg}$. Height (m) was determined through a stadiometer (Sanny, ES2030, São Paulo, Brazil).

Functional capacity was checked using the Rikli and Jones ${ }^{16}$ Senior Fitness Test battery, with tests that assess physiological attributes (dynamic agility/balance, lower limb and upper limb strength, and cardiorespiratory fitness) to perform normal daily activities in a safe and independent manner, without undue fatigue.

The maximum dynamic force was verified with the one-repetition maximum (1RM) test in the machines: Vertical Supine, Smith Machine and
Articulated Row (Physicus, São Paulo, Brazil), contemplating the pushing, pulling, squatting and standing up actions. For muscle power analysis, the same exercises were used with an external load of 50\% of 1RM and the velocity was determined using a linear encoder connected to the central unit of an integrated data analysis program (Musclelab ${ }^{\circledR}$, Ergotest Innovation, Porsgrunn, Norway). The encoder was connected to the bars (Supine, Smith Machine and rower) to register its displacement in the frequency of $100 \mathrm{~Hz}$. After registration of the traveled distance, the technique of differentiation was used to calculate the speed and acceleration of the bar. The average power developed in the concentric phase of the exercise was measured through these calculations. The participant performed a warm-up that consisted of a series of 10 - 15 repetitions and, after three minutes, they performed repetitions at the maximum possible velocity with the load of $50 \%$ of 1 RM until demonstration of fatigue.

\section{Statistical analysis}

Data were submitted to statistical treatment in the Statistical Package for Social Sciences (SPSS) 24.0 for Windows. After confirming the normality of the data set through the Shapiro-Wilk test, descriptive statistics with means and standard deviations was used to characterize the groups and observed variables. Data were analyzed through a $2 \times 2$ ANOVA with post hoc SIDAK test to verify the differences between the interventions. All tests were two-tailed, with significance level of $5 \%$. The effect size ( $d$ ') was calculated according to the methodological procedures defined by Cohen ${ }^{17}$.

\section{RESULTS}

The present study found that functional training (FT) promoted significant improvements in balance/agility, lower limb strength, upper limb strength, cardiorespiratory fitness and isometric strength in healthy older women when compared to traditional training. Table 2 presents the results of interventions in the functional tests conducted with healthy older women.

However, in relation to the conventional tests of maximum dynamic force and muscle power, no statistically significant differences were found between groups. (Table 3)

\section{DISCUSSION}

The main finding of the present investigation is that although both protocols demonstrated efficiency in the improvement of variables related to physical fitness of the elderly, FT seemed to promote greater gains in 


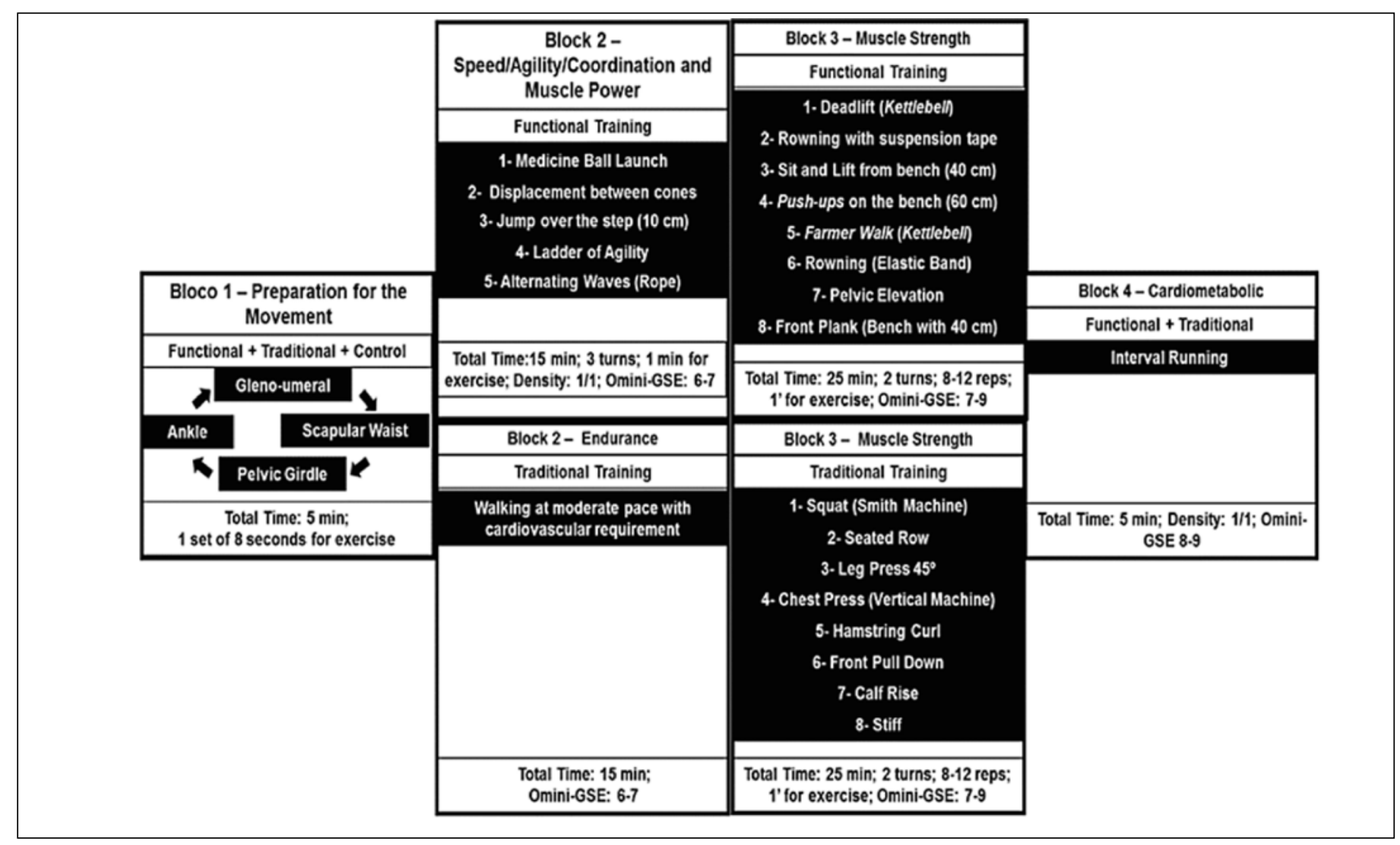

Figure 2. General description of the training sessions in the Functional Training (FT) and Traditional Training (TT) groups.

Table 1. Characteristics of the participants in the Functional Training (FT) and Traditional Training (TT) groups. Means \pm standard deviations are presented.

\begin{tabular}{c|c|c}
\hline Variables & FT & TT \\
\hline Age, years & $64.6 \pm 5.5$ & $66.6 \pm 5.6$ \\
\hline Height, $\mathrm{cm}$ & $154.1 \pm 6.7$ & $154.9 \pm 7.8$ \\
\hline Body weight, $\mathrm{kg}$ & $70.0 \pm 12.2$ & $67.2 \pm 15.0$ \\
\hline BMI, $\mathrm{kg} / \mathrm{m}^{2}$ & $29.4 \pm 5.0$ & $27.8 \pm 5.2$ \\
\hline MMSE, points & $24.3 \pm 3.3$ & $25.5 \pm 3.6$ \\
\hline
\end{tabular}

No significant difference $(p<0.05)$ was found for any of the variables analyzed based on at-test for independent samples.

functional capacity for daily life activities when compared to TT. Similar findings were found by De Vreede et al. ${ }^{5}$ with a randomized 12-week study, where functional exercises produced greater gains in functional capacity when compared to traditional exercises. Although the latter demonstrated a greater gain of muscular strength, this did not translate into improved performance of activities of daily living.

In performance during functional tests, Milton et al. ${ }^{11}$ compared functional exercises (specific to daily needs) with traditional exercises, and after 4 weeks of intervention identified a better functional training response in dynamic agility/balance (13\%), strength of lower limbs (13\%) and upper limbs (14\%) and cardiorespiratory endurance (7\%). The present study found similar incremental values in dynamic agility/balance (7.6\%), lower limb strength (15.3\%) and upper limb strength (11.0\%), and cardiorespiratory endurance (10.7\%) in relation to traditional training, ratifying the results.

A possible explanation for these findings is that the differentiated exercises of the FT can activate spinal stabilizing muscles with more intensity and stimulate postural control centers, so that the conditions of agility and dynamic balance can be more efficiently developed. ${ }^{18}$ For adaptations in muscle strength, multi-articular exercises act integrating the body structures, causing a greater activation of motor units and an intermuscular coordination that can make the transference to daily activities possible ${ }^{19}$.

As for cardiorespiratory fitness, the metabolic characteristic of the functional circuits used in blocks 2 and 3 may have promoted changes in the mechanisms responsible for oxygen transport and use, increase in the oxidative capacity of muscle cells, and in glycogen and phosphate degradation. ${ }^{20-22}$

It has been frequently reported in the scientific community that dynamic exercises with greater motor complexity and that resemble movements of activities of daily living are more likely to be transferred into the individuals' specific needs. ${ }^{5,23}$ In a six-week study with application of specific exercises for activities of daily living or strength training using elastic bands, Krebs et al.' found that although improved lower limb strength was observed in both groups, the group that performed exercises proposed in the FT presented higher gait speed, higher maximum knee torque, better dynamic balance and better coordination during the execution of tasks of daily living.

However, traditional strength training protocols have proven their effectiveness in developing strength, improving balance and walking ability and reducing the incidence of falls.,3,24 In the present study, the older women who practiced the traditional analytical exercises also demonstrated a significant performance in intragroup analysis (pre- vs. post-intervention) in all applied functional tests, except in the six-minute walk test, suggesting that greater control of training variables, safety and greater possibility of adding external load provided by traditional exercises are also translated into improvement of physical function of the elderly.

Moreover, both groups experienced similar significant increases in the maximal dynamic strength and muscle power tests, corroborating the results obtained by Lohne-Seiler et al., ${ }^{25}$ where after 11 weeks of intervention found no significant differences between groups that practiced functional strength exercises versus traditional strength exercises with respect to the traditional maximum dynamic force test and muscle power in the Leg-press test. However, it is worth noting that the maximum dynamic strength and muscle power tests applied in the present investigation were executed in machines used by the $T$ group in daily basis, and their significant performance may be related to the training specificities to the tests. 
Table 2. Functional changes after eight weeks of functional training and traditional training in sedentary older women.

\begin{tabular}{|c|c|c|c|c|c|c|c|c|c|}
\hline \multirow{2}{*}{$\begin{array}{c}\text { Senior Fitness } \\
\text { test }^{16}\end{array}$} & \multicolumn{3}{|c|}{ Functional Training $(n=16)$} & \multirow[b]{2}{*}{ SE } & \multicolumn{3}{|c|}{ Traditional Training $(n=16)$} & \multirow{2}{*}{$\mathbf{P}$} & \multirow{2}{*}{ SE } \\
\hline & Pre-intervention & Post- intervention & $\Delta \%$ & & Pre- intervention & Post- intervention & $\Delta \%$ & & \\
\hline Sit and reach $(\mathrm{cm})$ & $3.8 \pm 6.0$ & $6.8 \pm 7.4^{\mathrm{a}}$ & 78.9 & 0.50 & $3.7 \pm 6.0$ & $5.4 \pm 6.2^{\mathrm{a}}$ & 45.9 & 0.58 & 0.28 \\
\hline Back scratch (cm) & $-8.7 \pm 5.9$ & $-3.8 \pm 5.7^{a}$ & 128.9 & 0.83 & $-9.3 \pm 11.4$ & $-6.4 \pm 10.4^{a}$ & 45.3 & 0.40 & 0.26 \\
\hline Sit-to-stand (rep) & $15.8 \pm 5.6$ & $22.6 \pm 4.8^{\mathrm{ab}}$ & 43.0 & 1.21 & $15.5 \pm 4.6$ & $19.6 \pm 2.7^{a}$ & 26.4 & 0.04 & 0.89 \\
\hline Elbow flexion (rep) & $17.4 \pm 2.77$ & $23.1 \pm 3.60^{\mathrm{ab}}$ & 32.7 & 2.05 & $16.1 \pm 2.7$ & $20.8 \pm 2.5^{a}$ & 29.1 & 0.05 & 1.74 \\
\hline Six-minute walk (m) & $534.1 \pm 50.2$ & $617.9 \pm 102.2^{\mathrm{ab}}$ & 15.6 & 1.66 & $529.5 \pm 51.3$ & $557.8 \pm 56.7$ & 5.3 & 0.05 & 0.55 \\
\hline
\end{tabular}

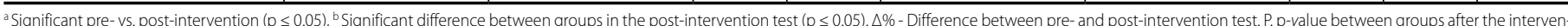
tion. SE- Size Effect.

Table 3. Changes in maximal dynamic strength and muscle power with eight weeks of functional training and traditional training in sedentary elderly women

\begin{tabular}{|c|c|c|c|c|c|c|c|}
\hline \multirow{2}{*}{ Tests } & \multicolumn{3}{|c|}{ Functional Training $(n=16)$} & \multicolumn{3}{|c|}{ Traditional Training $(n=16)$} & \multirow[b]{2}{*}{$P$} \\
\hline & Pre-intervention & Post- intervention & $\Delta \%$ & Pre- intervention & Post- intervention & $\Delta \%$ & \\
\hline Supine $(\mathrm{kg})$ & $51.6 \pm 9.03$ & $58.6 \pm 9.53$ & 7.06 & $48.5 \pm 10.1$ & $59 \pm 12.6^{d}$ & 10.4 & 0.93 \\
\hline Rowing $(\mathrm{kg})$ & $35.3 \pm 6.3$ & $42.46 \pm 7.68$ & 7.13 & $31.75 \pm 6.22$ & $39.6 \pm 8.0^{\circ}$ & 7.87 & 0.32 \\
\hline Squatting $(\mathrm{kg})$ & $70.1 \pm 18.6$ & $84.5 \pm 14.7^{\mathrm{d}}$ & 14.4 & $68.5 \pm 17.5$ & $84.0 \pm 17.0^{\circ}$ & 15.5 & 0.93 \\
\hline Supine (W) & $105.9 \pm 23.5$ & $118.9 \pm 25.7$ & 13.0 & $104.3 \pm 28.7$ & $119.5 \pm 35.0^{d}$ & 15.2 & 0.95 \\
\hline Rowing (W) & $153.6 \pm 36.3$ & $172.0 \pm 37.0^{\mathrm{d}}$ & 18.4 & $146.3 \pm 39.6$ & $161.8 \pm 46.0^{d}$ & 15.5 & 0.50 \\
\hline Squatting $(W)$ & $151.8 \pm 37.3$ & $175.7 \pm 37.9^{\mathrm{d}}$ & 21.1 & $147.2 \pm 40.3$ & $164.5 \pm 39.3^{\circ}$ & 17.3 & 0.42 \\
\hline
\end{tabular}

Significant difference pre- vs. post-intervention $(p \leq 0.05)$, b Significant difference between the groups in the post-intervention test $(p \leq 0.05) . \Delta \%$ - Difference between pre- and post-intervention test. P. p-value between groups after the intervention.

Another important finding of the present study was the high adherence to both interventions, demonstrated by the absence of sample loss. This suggests that more dynamic training protocols with varied activities are extremely challenging and motivating to regular practice.

The present investigation applied proposals of exercises with particularities not yet popularized in the literature as an attempt to encourage systemic adaptations through varied stimuli. Although the present study provided important information about the benefits of FT to physical fitness determinants in older women, we suggest that future research control for the speed of movement and include longer periods of intervention.

\section{CONCLUSION}

Based on the sample and the analyzed conditions, we conclude that both interventions are efficient in improving the physical fitness of sedentary older women. However, functional training induces better adaptive responses to functionality and may be an interesting alternative to mitigate the deleterious effects caused by advancing age. The proposal of the present investigation becomes pertinent in the sense that seeks to reaffirm the foundations that guide the prescription of functional training and the search for more effective interventions in health promotion.

All authors declare no potential conflict of interest related to this article.

AUTHORS' CONTRIBUTIONS: Each author made significant individual contributions to this manuscript. AGRN (0000-0002-2838-6684)*: writing of the article, revision and performance of procedures; MSS (0000-0001-8549-2136)* writing and revision of the article; RJSS (0000-0002-4578-7666)*: data analysis and writing of the articles; JMS (0000-0003-1432-0737)*: writing of the article, statistical analysis and intellectual concept of the article; MESG (0000-0003-3338-1359)*: writing of the article, statistical analysis, intellectual concept of the article and drafting of the entire research project. *ORCID (Open Researcher and Contributor ID).

\section{REFERENCES}

1. Chodzko-Zajko WJ, Proctor DN, Singh MAF, Minson CT, Nigg CR, Salem GJ, \& Skinner JS. Med Sci Sports Exerc. 2009;1510-30

2. Westcott WL. Resistance training is medicine: effects of strength training on health. Curr Sports Med Rep. 2012;11(4):209-16.

3. Cadore LE, Rodriguez-Mañas $L$, Sinclair A, Izquierdo M. Effects of diferente exercise interventions on risk of falls gait ability, and balance in phisically frail older adults: A systematic review. Rejuvenation Researche. 2013;16(2):105-14.

4. Latham NK, Bennett DA, Stretton CM, Anderson CS. Systematic review of progressive resistance strength training in older adults. J Gerontol A Biol Sci Med Sci. 2004;59(1): 48-61.

5. DeVreede PL, Samson MM, Van Meeteren NLU, Duursma S A, Verhaar HJJ. Functional-Task Exercise Versus Resistance Strength Exercise to Improve Daily Function in Older Women: A Randomized, Controlled Trial. J Am Geriatr Soc. 2005; 53(1):2-10.

6. Krebs DE, Scarborough DM, Mcgibbon CA. Functional vs. Strength Training in Disabled Elderly Outpatients. Am J Phys Med Rehabil. 2007;86(2):93-103.

7. Liu C, Shiroy DM, Jones LY, Clark DO. Systematic review of functional training on muscle strength, physical functioning, and activities of daily living in older adults. Eur Rev Aging Phys Act. 2014;1,95-106.

8. Da Silva-Grigoletto ME, Brito $\mathrm{CJ}$, Heredia JR. Treinamento funcional: funcional para que e para quem? RBCDH. 2014;16(6):608-17.

9. La Scala Teixeira CV, Evangelista AL, Novaes JS, Da Silva Grigoletto ME, \& Behm D. G. "You're Only as Strong as Your Weakest Link": A Current Opinion about the Concepts and Characteristics of Functional Training. Frontiers in Physiology. 2017;8-643.

10. Whitehurst MA, Johnson BL, Parker CM, Brown LE, Ford AM. The benefits of a functional exercise circuit for older adults. J Strength Cond Res. 2005;19(3):647-51.

11. Milton D, Porcari J, Foster C, Gibson M, Udermann B. The effect of functional exercise training on functional fitness levels of older adults. Gunderson Lutheran Med J. 2008; 5(1): 4-8.

12. Thomas JR, Nelson JK, Silverman SJ. Métodos de pesquisa em atividade física, $5^{a}$ Ed. Porto Alegre: ArtMed, 2007

13. Gomes A, Pereira RA, \& Yokoo EM. Caracterização do consumo alimentar de adultos por meio de questionário simplificado: contribuição para os estudos de vigilância alimentar e nutricional. Cadernos Saúde Coletiva. 2015;23(4).

14. Da Silva-Grigoletto ME, Viana-Montaner BH, Heredia JR, Mata F Peña G, Brito CJ et al. Validación de la escala de valoración subjetiva del esfuerzo OMNI-GSE para el control de la intensidad global en sesiones de objetivos múltiples en personas mayores. Kronos. 2013;12(1):32-40.

15. Tombaugh TN, Mcintyre NJ. The mini-mental state examination: a comprehensive review. Journal of the American Geriatrics Society. 1992;40(9):922-35.

16. Rikli RE, Jones CJ. Development and validation of a functional fitnesstest for community-residing older adults. J Aging Phys Activity. 1999; 7(6): 129-61.

17. Cohen J. Things I have learned (so far). Am Psychol. 1990;45(12):1304-12.

18. Hunter SK, Pereira HM, Keenan KG. The aging neuromuscular system and motor performance. J Appl Physiol. 2016;121(4):982-95.

19. Wirth K, Hartmann H, Sander A, Mickel C, Szilvas E, Keiner M. The impact of back squat and leg-press exercises on maximal strength and speed-strength parameters. J Strength Cond Res. 2016;30(5):1205-12

20. Kilka B, Jordan C. High-intensity circuit training using body weigth: Maximum results with minima investment. ACSM'S Health \& Fitness Journal. 2013;17(3): 8-13.

21. Milanović Z, Sporiš G, Weston M. Effectiveness of High-Intensity Interval Training (HIT) and Continuous Endurance Training for VO2max Improvements: A Systematic Review and Meta-Analysis of Controlled Trials. Sports Med. 2015;45(10):1469-81.

22. Romero-Arenas S, Blazevich AJ, Martínez Pascular M, Pérez-Gómez J, Luque, AJ, López Román FJ, et al. Effects of high-resistance circuit training in an elderly population. Exp Gerontol. 2013;48(3):334-40.

23. Rusese JRS, Navega MT. Evaluation of balance, mobility and flexibility in active and sedentary elderly women. Rev.Bras.Geriatr.Gerontol. 2014;17(4):785-93.

24. Pedersen BK, \& Saltin B. Exercise as medicine-evidence for prescribing exercise as therapy in 26 different chronic diseases. Scand J Med Sci Sports. 2015;25(3):1-72.

25. Lohne-Seiler H, Torstvei MK, Anderssen SA. Traditional versus functional strength training: effects on muscle strength and power in the elderly. J Aging Phys Act. 2013; 21(1):51-70. 